\title{
RENEWABLE ENERGY AND ENERGY MANAGEMENT'S INFLUENCE ON JOB CREATION
}

\section{OBNOVLJIVA ENERGIJA I UTICAJ ENERGETSKOG MENADŽMENTA NA OTVARANJE RADNIH MESTA}

\author{
Dr Sanja Marković \\ Visoka poslovna škola strukovnih studija „Prof. dr Radomir Bojkovićc Kruševac \\ e-mail: teodorasanja@gmail.com \\ Dr Snežana Mijailović \\ Visoka poslovna škola strukovnih studija „Prof. dr Radomir Bojković“ Kruševac \\ e-mail: snezana.km@ptt.rs
}

\section{Sažetak}

Decenijama tokom prošlosti pretpostavljalo se da je zaštita životne sredine usko povezana sa visokim finansijskim troškovima. Međutim, u slučaju obnovljivih izvora energije, veliki broj studija govori suprotno: da veća upotreba energetskih sistema, čiji se rad zasniva na korišćenju obnovljivih izvora energije, obezbeđuje ekonomsku korist kroz: inovacije i investicije u otvaranje novih radnih mesta, čime se povećava standard i bruto nacionalni dohodak stanovništva, povećava se sigurnost snabdevanja energijom, te istovremeno štiti ekonomija od političkih i ekonomskih rizika, smanjuje enrgetska zavisnost i emisija $\mathrm{CO} 2$. Uticaj energetskog menadžmenta je veoma značajan za kreiranje novih radnih mesta, posebno u onim regionima čija industrija je bazirana na korišćenju tradicionalnih izvora energije. Obnovljivi izvori energije imaju potencijal da postanu značajan izvor zapošljavanja u Srbiji, otvarajući mogućnost zaposlenja u širokom spektru poslova.

\section{Abstract}

For decades in the past it was often assumed that environmental protection inevitably comes with a high financial cost. However, an increasing number of studies are finding precisely the opposite is true in the case of renewable energy: that greater use of renewable energy systems provides economic benefits through investments in innovation, and through new job creation and thereby increases the standard of living, while at the same time protecting the economy from political and economic risks, increases security of energy supply, reduces the energy dependence and emission of $\mathrm{CO} 2$, increases the gross national income. The involvement of energy managament is highly important for the future of creating new employment, especially in the regions whose industrial mix was based on traditional energy resources. Renewable energy sources have the potential to become significant source of jobs in Serbia, opening employment opportunities in a wide variety of jobs. 
Ključne reči: zaposlenost, obnovljivi izvori energije, energetski menadžment

Keywords: employment, renewable energy sources, energy management

\section{Introduction}

Natural reserves of fossil energies are limited and concentrated in a relatively small number of countries. Illustrative fact is that about $60 \%$ of World oil reserves are located in the Middle East, and about $60 \%$ reserves of natural gas in just three countries: Russia, Iran and Qatar. Coal reserves are available in almost every country worldwide, with recoverable reserves in around 70 countries. The biggest coal reserves are found in the United States of America (USA), Russia, China and India. Coal reserves in the world have been estimated to over 861 billion tones of proven coal reserves worldwide. This means that continuing with the current rate of exploitation, exploitation of oil reserves will be exhausted in less than 40 years of gas reserves for 60 years, and coal reserves of about 200 years.

The most intensive use of fossil fuels is present in countries with highly developed economies, such as the USA with a share of $24,4 \%$, and the EU, with $15 \%$, followed by: China, Russia and Japan, while the rest of the World spends only $37,2 \%$ of fossil energy. The most serious problem that confronts mankind is the rapid growth of population. The world population is estimated to number of 7,145 billion inhabitants according to United States Census Bureau. Under present day actuarial conditions the population eventually would stabilize at around 11 billion by the year 2050. Increasing of global population will certainly cause an increase of energy consumption. Increasing of energy consumption is not, caused only by a population growth, but also with the increase in the standard of living. By 2030, population of underdeveloped countries will still primarily use their own strength and the strength of the animal, while the population of developed countries will use significant amounts of energy in industry, transport, and heating and cooling air space in the buildings. The faster economic and industrial development requires more intensive use of energy resources, which are limited, so that development of the countries depends on the increase of energy efficiency and development of the new technologies which are based on the use of renewable energy sources (RES): biomass, wind, geothermal, solar, ocean waves, tidal, ocean thermal energy conversion (OTEC), and hydro energy. Greater use of RES protect economy from uncertainty of energy supply while at the same time provides economy benefit trough job creation.

\section{Definition of Energy Management}

"Energy Management generally represents the managing of the energy's flow parameters within an organization, from the manufacturing process and supply of the energy source and energy, through a process of transformation to final energy use. Here, the concept of energy's flow parameters implies various quantitative and qualitative parameters with witch it is possible to describe some of these processes from the technical, economic and social aspects, as well as from the aspect of the environment."'[1]

The term Energy management does not imply energy managing, but managing an organization of any type (state, local governments (municipalities), a company from the aspect of energy, because energy is not a target in itself, but the goal is an efficient use of energy. "Energy management is: The judicious and effective use of energy to maximize profits (minimize costs) and enhance competitive positions. This rather broad definition covers many operations from product and equipment design through product shipment. Waste minimization and disposal also presents many energy management opportunities. The primary objective of energy management is to maximise profits or minimize costs. “ [2]

If the primary goal of energy management is increasing energy efficiency and the main activities of energy management are directed to that goal, it is possible to realize $5-15 \%$ of 
energy savings at a very conservative approach - with little or no investment. Looking at the current situation in terms of energy efficiency in companies in Serbia, this potential is even more significant and ranges from $20-25 \%$. A similar situation is in other countries of Western Balkans region. If energy management possesses "aggressive program", energy consumption at the state level can be reduced by $50 \%$ provided that there are no barriers to the implementation of the application of alternative energy sources and new technologies.

\section{Job creation in Renewable Energy electricity sector}

Renewable energy has some important advantages over conventional fossil fuels. Improving energy efficiency or expanding $\mathrm{RE}$ resources reduces the risk of both combusting carbon-based fossil fuels and relying too much of exhaustion of coal, oil and natural gas supplies. In the wake of the recent financial crisis, $\mathrm{RE}$ is also widely promoted for its ability to create jobs. Energy management at the national level should advance these technologies, because they stimulate economy, as well as protect against global climate change and energy insecurity. According to IRENA (International renewable Energy Agency), estimated gross global renewable energy employment increased from 1,3 to more than 6,5 million jobs worldwide between 2004 and 2013 (Picture 1).

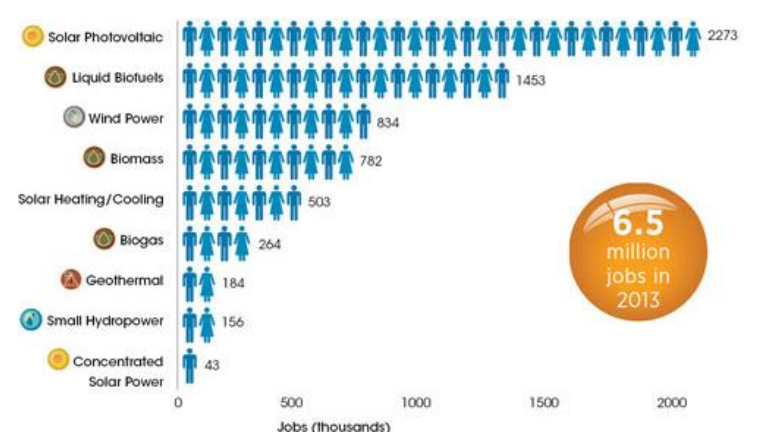

Picture 1. Renewable energy employment by technology

Solar photovoltaic (PV) and wind power remain the most dynamic RE technologies.
Solar PV sector is estimated to 2273000 jobs in 2013. Most studies conclude that a high proportion of jobs are related to fuelbased technologies. The biofuel sector is estimated to account for almost a quarter of the jobs in the renewable energy industry (1,5 million in 2010). The largest number of RE jobs are found in China, Brasil, Germany, India and in USA. (Picture 2)

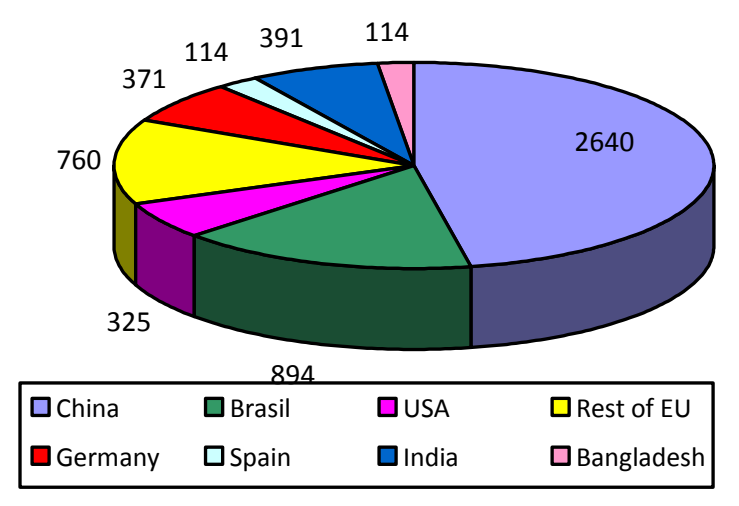

Picture 2. Renewable energy employment in selected countries

The five top Solar photovoltaic - PV cell manufacturers are from China and the USA. The five top wind turbine manufacturers are from Denmark, China, the USA, and Germany. These countries offer long - term policy support to renewable energy, and have significant national markets for the appropriate technologies.

"The Economic Benefits of Clean Energy," a report by the University of Massachusetts, determined that:

- Spending directed toward a clean-energy investment program will have a much larger positive impact on jobs than spending in other areas, including the oil industry even when taking into account all phases of oil production, refining, transportation, and marketing.

- Spending a given amount of money on a clean-energy investment agenda generates approximately 3.2 times the number of jobs within the United States as does spending the same amount of money within the fossil fuel sectors. [3]

The report noted that "clean-energy investments create in excess of three times more jobs per agiven amount of spending 
than the fossil fuel industry" due to three factors. Clean energy jobs:

- Are relatively labor intensive compared to oil production, which is more capital intensive

- Employ more domestically produced content or economic activities

"Produce far more jobs at all pay levels higher as well as lower - compared to the fossil fuel industry"

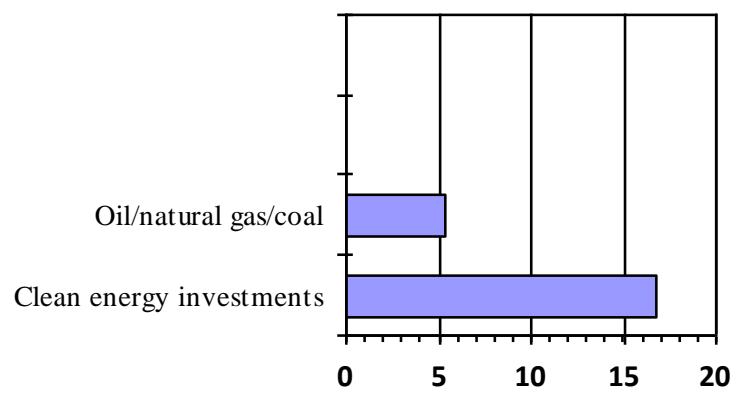

Picture 3. Job creation through $\$ 1$ million of USA spending

Energy supply systems employ many people during their life cycle, from construction and operation till decommissioning. [4] Local societies where plants were established, based their development and prosperity for many decades. Table 1 presents the average jobs created by a power plant of $500 \mathrm{MW}$ acoording to results of Energy Power Research Institute (EPRI), 2001; Renewable Energy Policy Project (REPP), 2001; US Department of Energy (USDOE), 1997).

Table 1. Average job creation for a power plant of 500MW in USA [5]

\begin{tabular}{|c|c|}
\hline Type of power plant & $\begin{array}{c}\text { Job creation (new } \\
\text { employees / 500MW }\end{array}$ \\
\hline Coal/lignite & 2500 \\
\hline Oil & 2500 \\
\hline Natural gas turbine & 2460 \\
\hline $\begin{array}{c}\text { Natural gas combined } \\
\text { cycle }\end{array}$ & 2460 \\
\hline Nuclear & 2500 \\
\hline Hydro & 2500 \\
\hline Wind & 5635 \\
\hline Photovoltaic & 5370 \\
\hline Biomass & 36055 \\
\hline Geothermal & 27050 \\
\hline
\end{tabular}

Renewable energy creates more jobs per GW in construction, manufacturing and installation, and in O\&M and fuel processing, than the fossil fuel industries.
„Investment in renewables also generates more jobs per dollar invested than the fossil fuel energy sector. The REPP study calculates that the solar PV industry generates 5,65 person-years of employment per million dollars in investment (over 10 years) and the wind industry generates 5,7 person-years of employment per million dollars in investment (over 10 years). In contrast, every million dollar invested in the coal industry generates only 3,96 personyears of employment, over the same time period.[6] If renewable energy power projects provide more new jobs than conventional - fossil energy projects, then they may stimulate more additional jobs and enhance incomes. The measurement unit is called "job-years" (a full time employee hired over 12 months) per unit of electricity produced. [7] The large numbers of studies are aimed to assessing the job market of various generation technologies, but most of the researches only assessed limited number of power generation technologies, with heterogeneous measurement units such as: "job-years per peak MW", "job per peak MW", "job-years per peak GWh", "job-years per average MW". Due to that, Wei, Patadia; S., Kammen compare 23 various studies [8] on the job creation potential on renewable energy, energy efficiency, low carbon sources nuclear power, covering nearly all main electricity power technologies on equal footing to calculate average lifetime employment per units of energy. In the Table 2, adopted from Wei et al. a detailed job generation summary of the studies analyzed were presented. As it can be seen in the table, some of renewable energy technologies were represented by many studies (wind and solar), some of the technologies (biomass and geothermal) were not represented so frequently, while for some renewable technologies, they were not available (large hydro, bio waste, tidal stream, wave energy). 
Table 2. Comparasion of jobs/GWh-years between technologies

\begin{tabular}{|c|c|c|c|c|c|}
\hline \multirow{3}{*}{$\begin{array}{l}\text { Energy } \\
\text { technolgy }\end{array}$} & \multirow{3}{*}{$\begin{array}{c}\text { Capa } \\
\text { city } \\
\text { facto } \\
\text { r } \\
(\%)\end{array}$} & \multirow{2}{*}{\multicolumn{4}{|c|}{$\begin{array}{c}\begin{array}{c}\text { Average employment over } \\
\text { life of facility }\end{array} \\
\text { Total job-years/GWh }\end{array}$}} \\
\hline & & & & & \\
\hline & & $\begin{array}{l}\text { CI } \\
\mathrm{M}\end{array}$ & $\begin{array}{c}\text { O\&M } \\
\text { and fuel } \\
\text { processing }\end{array}$ & Total & $\begin{array}{c}\text { Av } \\
\mathrm{g}\end{array}$ \\
\hline Biomass 1 & 85 & 0,01 & 0,21 & 0,22 & \multirow{2}{*}{0,21} \\
\hline Biomass 2 & 85 & 0,03 & 0,16 & 0,19 & \\
\hline $\begin{array}{c}\text { Geothermal } \\
1\end{array}$ & 90 & 0,02 & 0,23 & 0,25 & \multirow{3}{*}{0,25} \\
\hline $\begin{array}{c}\text { Geothermal } \\
2\end{array}$ & 90 & 0,06 & 0,22 & 0,27 & \\
\hline Geothermal3 & 90 & 0,01 & 0,21 & 0,22 & \\
\hline $\begin{array}{l}\text { Landfill } \\
\text { gas }\end{array}$ & 85 & & 0,31 & 0,32 & 0,72 \\
\hline Small Hydro & 55 & 0,03 & 0,24 & 0,27 & 0,27 \\
\hline Solar PV 1 & 20 & 0,84 & 0,57 & 1,42 & \multirow{3}{*}{0,87} \\
\hline Solar PV 2 & 20 & 0,74 & 0,21 & 0,95 & \\
\hline Solar PV 3 & 20 & 0,16 & 0,07 & 0,23 & \\
\hline $\begin{array}{c}\text { Solar } \\
\text { Thermal } 1\end{array}$ & 40 & 0,12 & 0,29 & 0,40 & \multirow{3}{*}{0,23} \\
\hline $\begin{array}{c}\text { Solar } \\
\text { Thermal } 2\end{array}$ & 40 & 0,05 & 0,11 & 0,16 & \\
\hline $\begin{array}{c}\text { Solar } \\
\text { Thermal } 3\end{array}$ & 40 & 0,07 & 0,06 & 0,13 & \\
\hline Wind 1 & 35 & 0,13 & 0,13 & 0,26 & \multirow{5}{*}{0,17} \\
\hline Wind 2 & 35 & 0,05 & 0,05 & 0,10 & \\
\hline Wind 3 & 35 & 0,14 & 0,06 & 0,20 & \\
\hline Wind 4 & 35 & 0,10 & 0,07 & 0,16 & \\
\hline Wind 5 & 35 & 0,03 & 0,09 & 0,13 & \\
\hline
\end{tabular}

Two function groupings were considered:

- construction, installation and manufacturing (CIM)

- operations, maintenance and fuel processing.

As it can be seen in Table 2, the only renewable energy technology which is not included is large hydroelectric. Lack or the low relevance of large hydropower for the specific research objective could be the reason for omission of this information.

\section{Identification of new jobs in the field of renewable energy}

Renewable energy sources have the potential to become significant source of jobs in Serbia, opening employment opportunities in a wide variety of jobs. Employment in renewable energies requires some skills that do not coincide with those related to the traditional sector, thus suggesting the convenience of identifying these new necessities and requirements.

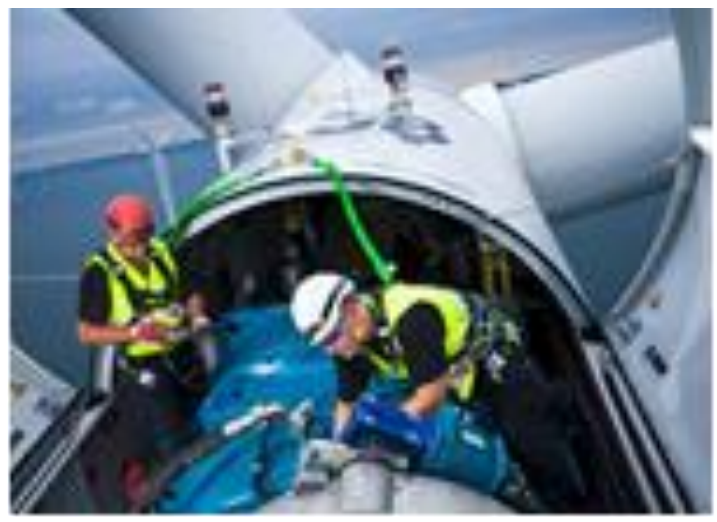

Picture 4. Electricians on wind generator

Average renewable energy jobs are highly skilled, although workers are also needed. Graduates are needed to fill positions in fields such as engineering, meteorology, project development and research and development, while system design, installation or construction are more likely to require vocational qualifications. For example, drilling and engineering skills are needed for heating and cooling technologies, engineers and technicians will be requred to process raw materials and assemble system components. Project development needs qualified personnel to conduct resource assessments, as well as system designers, energy officers, buissness managers, financial analysts etc. A nuber of unskilled jobs may be created in construction, transport, etc. 
Table 3. Skills and professional profiles linked to a RE employment

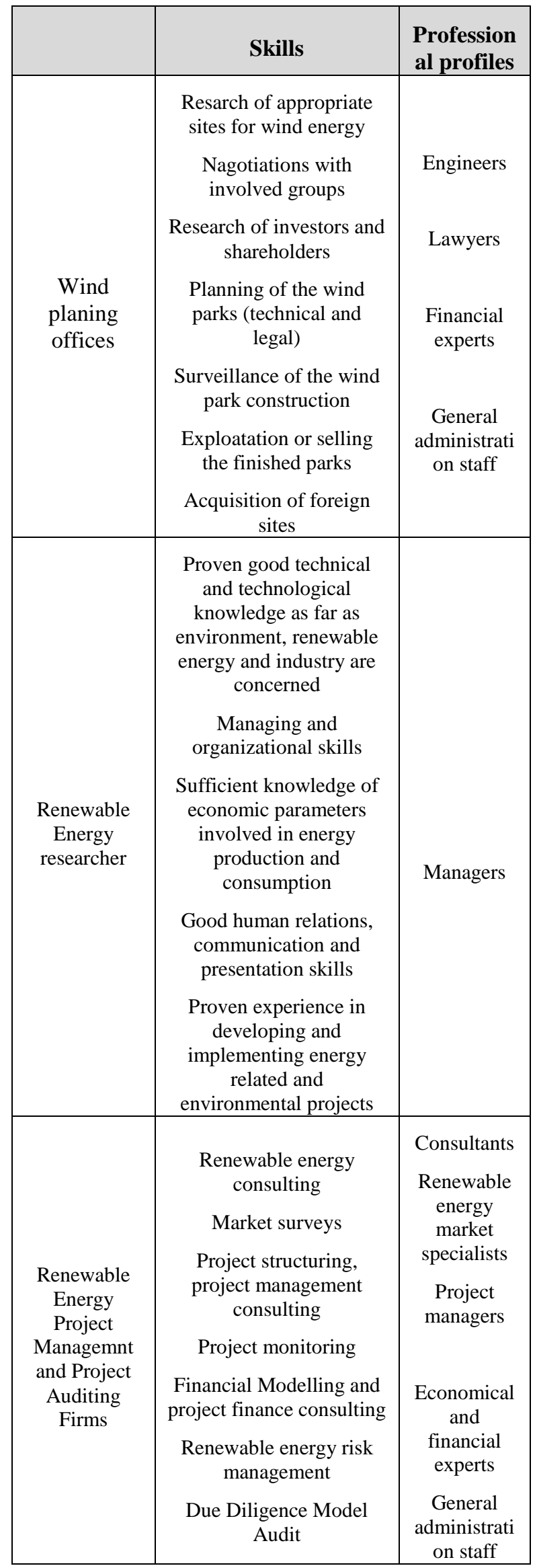

\begin{tabular}{|c|c|c|}
\hline $\begin{array}{l}\text { Photovoltaic } \\
\text { and Solar } \\
\text { Thermal } \\
\text { Manufactuers }\end{array}$ & $\begin{array}{c}\text { Production and } \\
\text { marketing of solar } \\
\text { thermal and photovoltaic } \\
\text { equipment }\end{array}$ & $\begin{array}{c}\text { Engineers, } \\
\text { scientists, } \\
\text { sales } \\
\text { managers, } \\
\text { production } \\
\text { managers } \\
\text { Financial } \\
\text { and legal } \\
\text { experts } \\
\text { Administrat } \\
\text { ion and } \\
\text { managemet } \\
\text { staff }\end{array}$ \\
\hline $\begin{array}{l}\text { Renewable } \\
\text { Energy } \\
\text { Producers } \\
\text { and } \\
\text { Suppliers }\end{array}$ & $\begin{array}{l}\text { Purchase and sale of } \\
\text { green electricity and } \\
\text { renewable fuels } \\
\text { Calculate the clients } \\
\text { electricity consumption } \\
\text { and match demand with } \\
\text { offer }\end{array}$ & $\begin{array}{l}\text { Sales, } \\
\text { engineers, } \\
\text { chemists, } \\
\text { biologists } \\
\text { General } \\
\text { administrati } \\
\text { on staff }\end{array}$ \\
\hline
\end{tabular}

Table 4. Renewable energy occupations identified as "difficult to fill" [9]

\begin{tabular}{|c|c|}
\hline Sector & Occupation \\
\hline Wind energy & $\begin{array}{c}\text { Project developers; service } \\
\text { technicians; data analysts; } \\
\text { electrical, computer, mechanical } \\
\text { and construction engineers }\end{array}$ \\
\hline Solar energy & $\begin{array}{c}\text { Photovoltaic and solar thermal } \\
\text { system installers and maintainers; } \\
\text { building inspectors }\end{array}$ \\
\hline Hydropower & $\begin{array}{c}\text { Electrical, operational and } \\
\text { maintenance engineers; } \\
\text { technicians; tradespersons; } \\
\text { sustainability specialists. }\end{array}$ \\
\hline Geothermal & $\begin{array}{c}\text { Trainers; geothermal engineers } \\
\text { Bioenergy }\end{array}$ \\
\hline $\begin{array}{c}\text { R\&D and design engineers; } \\
\text { service technician; trainers }\end{array}$ \\
\hline
\end{tabular}

\section{Conclusion}

Increased use of renewable energy, in addition to the obvious economic effects, such as reducing consumption of imported energy and reducing environmental pollution, hired to domestic capital, prompted the work of small and mediumsized enterprises, as well as the domestic production of equipment for the use of these energy sources. It would create new jobs and it would employ people from the local community. It would lead to the 
development of rural areas of the country, because most of the renewable energy is right there, in those areas which are economically least developed. In this paper, we have shown the perspectives of energy employment generated by renewable energies according to skill requirement analysis which has two levels of specialization, the first relating to engineering and technical skills, while the second refers to installers.

\section{Bibliografija}

1. Karamarković V., et al., Instructions for making the energy balance in the municipalities, Ministry of Mines and Energy, Belgrade, 2007

2. Capehart B.L., Turner C., W., Kennedy, W.J., Guide to Energy Management - 5th ed., The Fairmont Press, Inc., Lilburn, Geo., USA, 2006

3. Pollin R., Heintz J., Peltier G., The Economcy Benefits of Investing in Clean Energy, Amherst: University of Massachusetts, 2009

4. Wang Wang J-J., Jing Y-Y, Zhang C-F., Yhao J-H., Review on multi-criteria decision analysis aid in sustainable energy decision-making, Renewable and Sustainable Energy Reviews 12, 2009
5. Chatzimourtidis A.I., Pilavachi, P.A., Multicriteria evaluation of power plants impact on the living standard using analytic hierarchy process, Energy Policy 36, 2008

6. Kammen, D.M., Kapadia, K., Fripp, M., Putting Renewables to Work: How Many Jobs Can the Clean Energy Industry Generate?" RAEL Report, University of California, Berkeley, 2004

7. Maxim, A., Sustainability assessment of elecricity generation technologies using weighted multi-criteria decision analysis, Energy Policy 65, 2014

8. Wei, M., Patadia; S., Kammen, D.M., Putting renewables and energy efficiency to work: How many jobs can the clean energy industry generate in the US?, Energy Policy 38, 2010

9. IRENA - International Renewable Energy Agency, Renewable Energy and Jobs Annual Review, 2014

\section{Istorija rada:}

Rad primljen: 19.04.2015.

Prva revizija: 06.05.2015.

Prihvaćen: 10.05.2015. 
